\title{
Long-term collection of benthic and benthopelagic organisms from a deep-water inlet offshore from Okinawa, Japan
}

\author{
Takashi Kuramochi $^{1}$, Yusuke Sudo ${ }^{2,4}$, Eishin Tamaki ${ }^{2,4}$, Kazuhito Shiroma $^{2}$, \\ Takeshi Naganuma ${ }^{3, *}$ \\ 12-6-3-504 Ashina, Yokusuka, Kanagawa 240-0104, Japan \\ ${ }^{2}$ Okinawa Prefectural Deep Sea Water Research Center, Kumejima-cho, Okinawa 901-3104, Japan \\ ${ }^{3}$ School of Biosphere Science, Hiroshima University, Higashi-hiroshima 739-8528, Japan \\ ${ }^{4}$ Present address: Okinawa Prefectural Fisheries and Ocean Research Center, Itoman, Okinawa 901-0305, Japan
}

\begin{abstract}
Deep seawater facilities inadvertently collect organisms from suction inlets and, thus, may serve as unique biological platforms. Organisms collected from a depth of $612 \mathrm{~m}$ offshore from Okinawa, Japan, were archived from 2000 to 2006. Of the total of 633 individuals collected, 550 specimens were examined and taxonomically identified; the remaining 83 samples were too seriously damaged to examine. As a result, a total of 63 species were identified, and taxa comprised 34 fishes, 23 crustaceans, 5 mollusks and 1 echinoderm. Although a weak tendency of year-to-year increase in the catch number was apparent, it should be confirmed by monitoring for a longer term. No clear seasonality for the catch number and species composition was observed. A significant decline in the number of the pleurobranchid Pleurobranchella nicobarica and an increase in the benthopelagic holothurian Enypniastes eximia were recorded during the study period; these variations may imply that unspecified environmental changes have occurred.
\end{abstract}

KEY WORDS: Deep-sea $\cdot$ Fish $\cdot$ Benthos $\cdot$ Long-term collection

\section{INTRODUCTION}

Deep seawater facilities have been constructed worldwide for thermal energy conversion and euphotic zone fertilization (to stimulate local aquaculture), as well as for other deepwater-related enterprises. Japan is one of the leading countries for deepwater utilization, and more than 15 public and private facilities are in operation. These facilities obtain deep seawater from tube mouths (water inlets) deployed at $200 \mathrm{~m}$ or deeper, from which deep-dwelling organisms are inadvertently suctioned. Those organisms are often regarded as screen-clogging nuisances, although they provide biological and ecological information otherwise difficult to obtain. The Okinawa Prefectural Deep Sea Water Research Center (ODRC), Japan, has collected and preserved suctioned specimens since its inception and, thus, serves as a unique deep-sea observatory for continuous long-term monitoring. Although species of special interest, such as those previously unknown and/or reclassified, have been reported from the ODRC facility (i.e. 10 publications in Japanese by Kuramochi et al. available on request), overall abundance and species composition of the suctioned organisms have not been fully analyzed. We present a record of deep-sea organisms collected at $612 \mathrm{~m}$ depth off- 


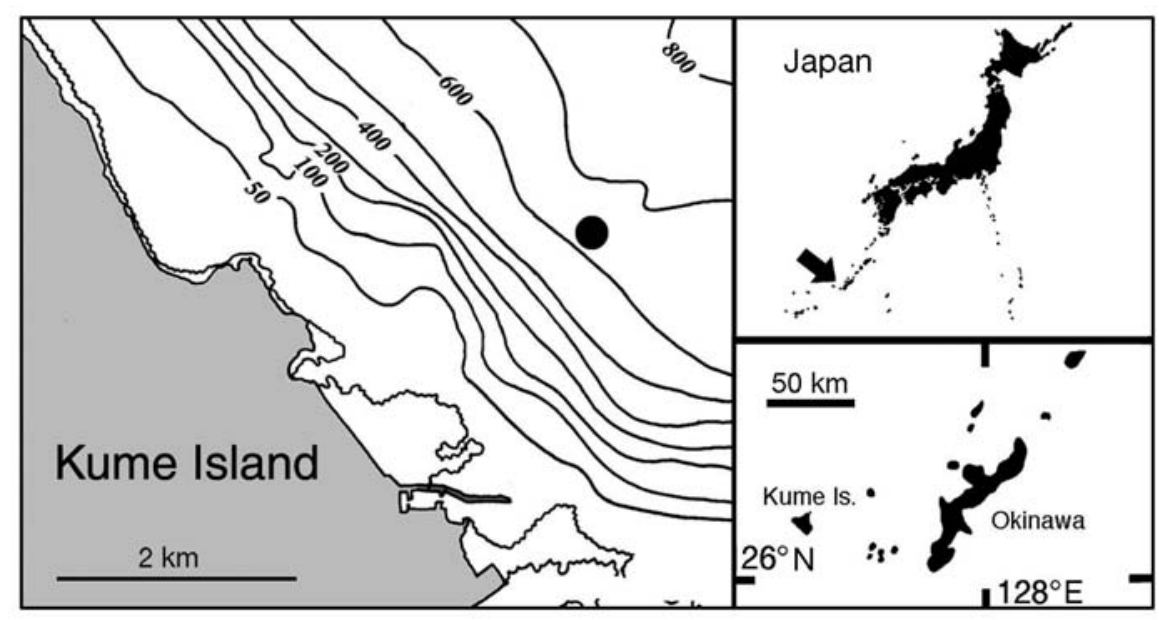

Fig. 1. Location of the suction inlet $(\bullet)$ at $612 \mathrm{~m}$ depth, offshore from Kume Island, Okinawa, Japan

shore from ODRC during the period from 2000 to 2006. This is the first inventory of deepwater dwellers collected at a fixed station over a 5 yr period.

\section{MATERIALS AND METHODS}

The ODRC laboratory is located on the northeastern shore of Kume Island, or Kumejima $\left(26^{\circ} 21.23^{\prime} \mathrm{N}\right.$, $126^{\circ} 48.45^{\prime} E_{\text {; Fig. }}$ ). The suction inlet for deepwater production (maximum $13000 \mathrm{~m}^{3} \mathrm{~d}^{-1}$, routinely 3400 to $11200 \mathrm{~m}^{3} \mathrm{~d}^{-1}$ ) is deployed $2.3 \mathrm{~km}$ offshore, $1.5 \mathrm{~m}$ above the seafloor at $612 \mathrm{~m}$ depth (Fig. 1). The length and inner diameter of the deepwater production tube are $1920 \mathrm{~m}$ and $280 \mathrm{~mm}$ (0.0615 $\mathrm{m}^{2}$ cross-sectional area), respectively, for the underwater section, and $607 \mathrm{~m}$ and $380 \mathrm{~mm}\left(0.1134 \mathrm{~m}^{2}\right)$ for the reef-to-land section, yielding an average cross-sectional area of $0.074 \mathrm{~m}^{2}$ and a total length of $2527 \mathrm{~m}$. Therefore, the maximum flow velocity of pumped deep water is $175.7 \mathrm{~km} \mathrm{~d}^{-1}$, or $2 \mathrm{~m} \mathrm{~s}^{-1}$ (routinely 0.5 to $1.75 \mathrm{~m} \mathrm{~s}^{-1}$ ). After a total passage length of $2527 \mathrm{~m}$ (minimum $21 \mathrm{~min}$, routinely 24 to $80 \mathrm{~min}$ ) through the tube, entrained organisms enter the damper pit.

The pit is installed with a $10 \mathrm{~mm}$ mesh screen (or strainer) for subsequent water flow, and organisms larger than $10 \mathrm{~mm}$ are trapped by the screen and retrieved for preservation in $10 \%$ formalin in seawater or $100 \%$ ethanol at room temperature in the dark. Trapped specimens were retrieved as soon as possible with a lag time from a half-day up to a maximum of $4 \mathrm{~d}$. Reduction in the flow rate due to clogging was never observed during the study period.

Although some of the trapped organisms were seriously damaged and, thus, left unexamined, most were examined for taxonomic identification. Specimens collected from 8 June 2000 to 13 November 2006 (2350 d) were carefully examined and identified morphologically by consulting classical taxonomic descriptions and ecological reports.

\section{RESULTS AND DISCUSSION}

While in situ measurement has not been conducted, temperature and $\mathrm{pH}$ of the water pooled on land have been recorded. Of a total of 3179 datasets, 8 unusual temperatures $\left(<8^{\circ} \mathrm{C}\right.$ and $\left.>12^{\circ} \mathrm{C}\right)$ and 2 unusual $\mathrm{pH}$ values $(<7)$, caused by instrumental and technical errors, were eliminated. Other fluctuations in temperature were probably due to fluctuations in pumping rate, i.e. volume of pumped water $\left(\mathrm{m}^{3} \mathrm{~d}^{-1}\right)$ and residence time on land. In fact, a significant correlation $(\mathrm{r}=0.482, \mathrm{n}=$ 2816, $\mathrm{p}<0.01$ ) between temperature and volume of the pumped water was found. However, there were no clear relationships between the numbers of suctioned specimens and the temperature or volume of the pumped water, and, therefore, are not discussed further in this study.

During the study period, a total of 633 organisms were suctioned and 550 specimens were identified, with 83 samples left unidentified because of excessive damage. Numbers of suctioned and retrieved organisms tended to increase from 2003 onward with a slight decline evident in 2006 (Table 1). If the data from the first and last years, 2000 and 2006, respectively, are normalized on a $365 \mathrm{~d}$ basis, this trend is largely unaffected. However, longer term monitoring is needed to confirm whether increases and decreases are episodic and reflect extant ecological fluctuations, or are influenced by certain environmental changes.

The taxonomic list and composition of the retrieved organisms are given in Table 1 and Fig. 2, respectively. A total of 63 species were identified, comprising 34 
fishes, 23 crustaceans, 5 mollusks and 1 echinoderm. No more than 8 individuals of a single fish species were caught per year, and only 3 fish species, namely Eptatretus okinoseanus (species identification number ID 30 in Table 1), Meadia abyssale (ID 37) and Laemoema palauense (ID 52), showed $>3$ individuals caught per year. Other fish species were represented by 3 or fewer individuals per year. On the other hand, crustaceans were dominated by a few species such as Plesionika semilaevis (ID 17; 97 individuals of a total of 295 crus-
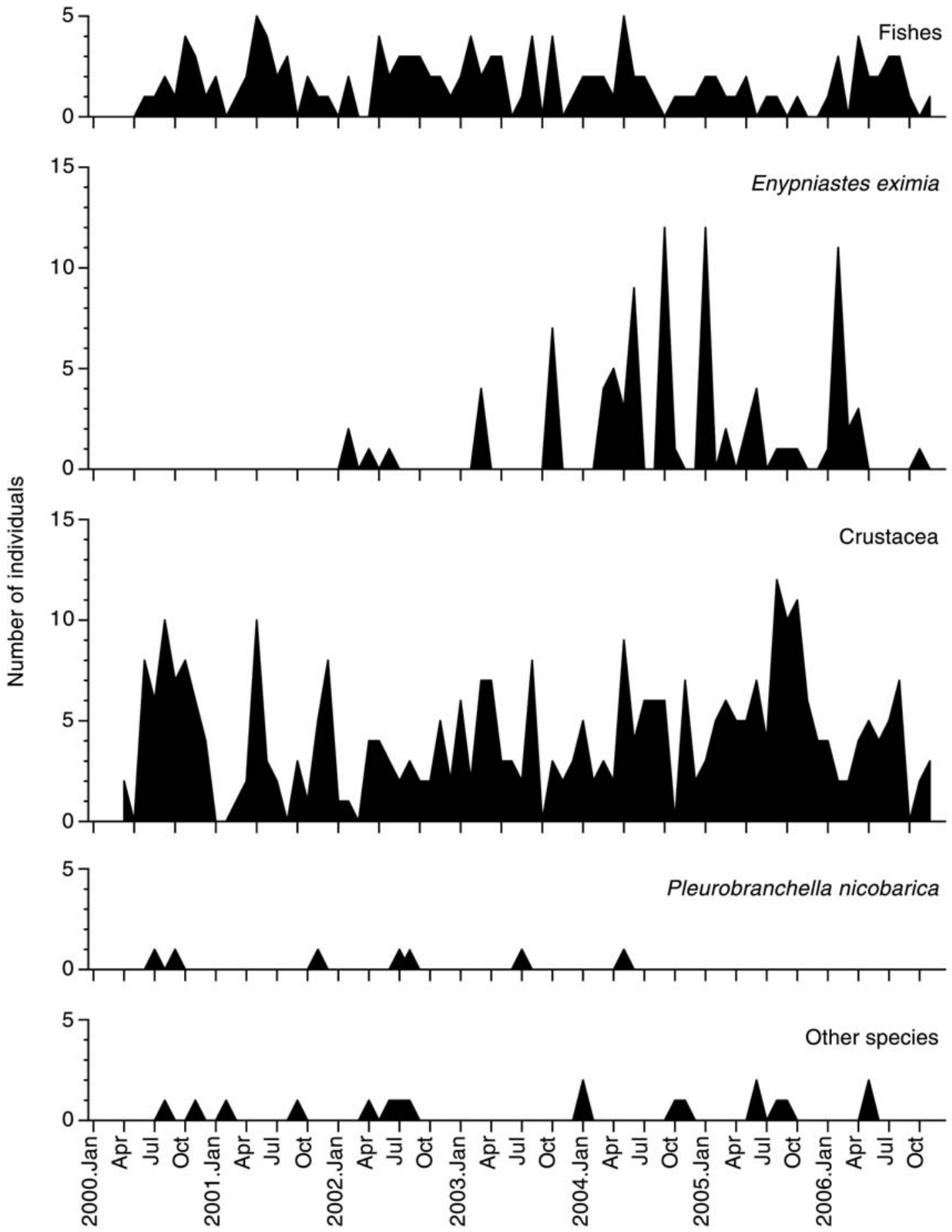

Fig. 2. Monthly catch of major taxonomic groups of the organisms collected from $612 \mathrm{~m}$ depth, offshore from Kume Island, Okinawa, Japan 


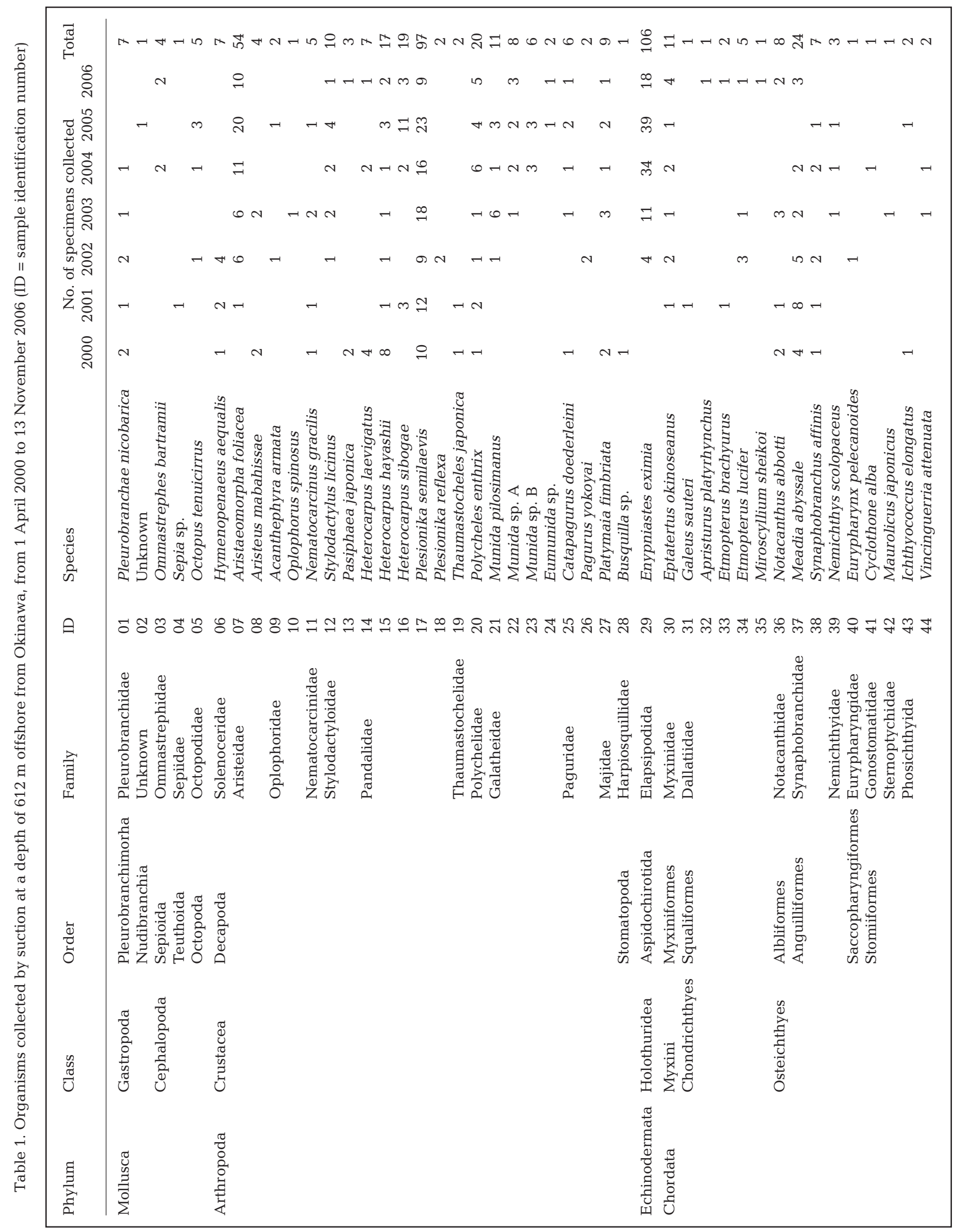




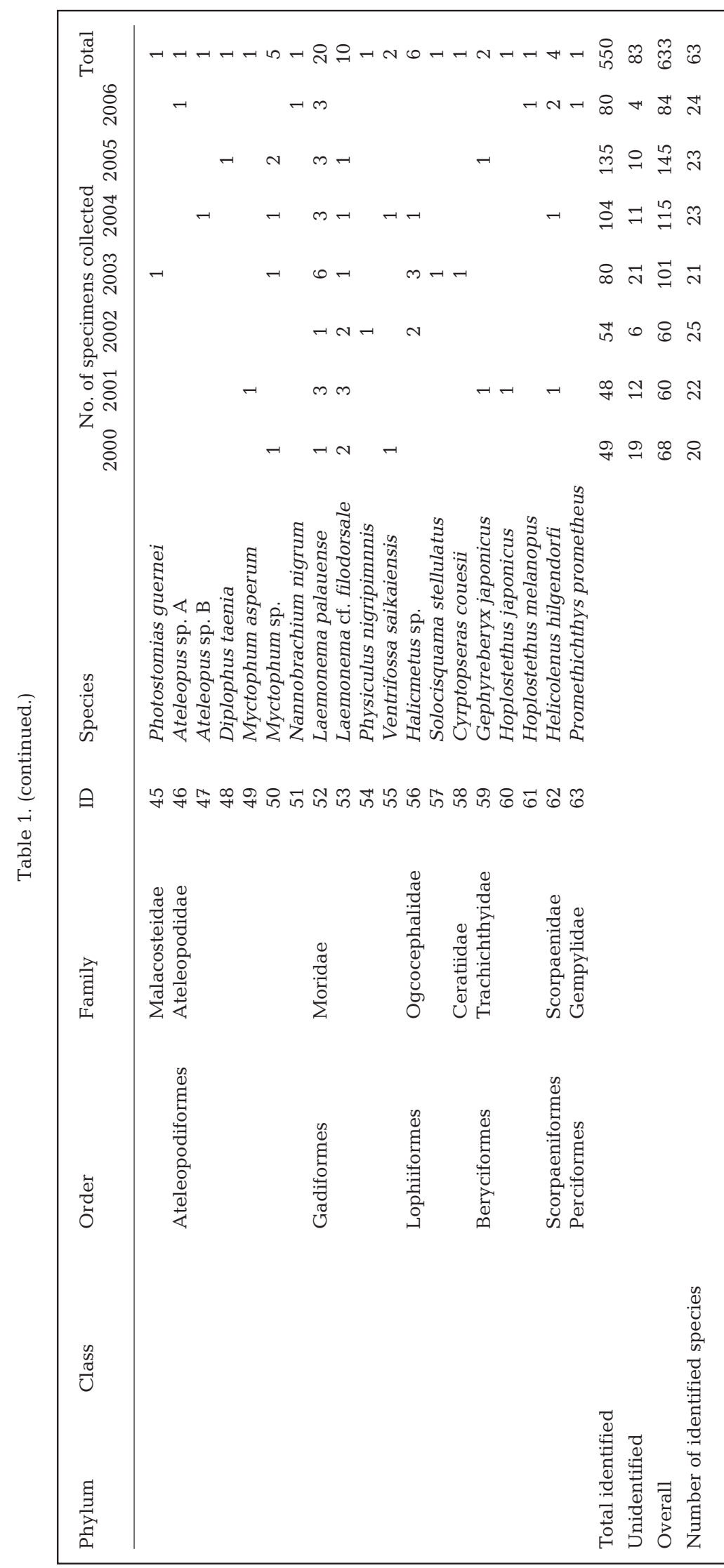

tacean specimens) and Aristaeomorpha foliacea (ID 7; 54 individuals). Plesionika semilaevis is a wellknown deep-sea species (Baba et al. 1986) and, thus, likely to occur widely in the Pacific Ocean and marginal seas. These 2 species accounted for $51 \%$ of the total crustacean catch and $27 \%$ of the all examined specimens.

In contrast to relatively constant numbers of species identified each year, 20 to 25 during the study period (Table 1), there were notable changes in the species compositions of the collected organisms (Fig. 2). In particular, the pleurobranchid, Pleurobranchella nicobarica Thiele 1925 (ID 01), was sampled in large proportions initially, but numbers declined afterwards. The type specimen of $P$. nicobarica was collected at the 296 m depth off Nicobar Island, Indian Ocean. Specimens of P. nicobarica have also been recorded from water depths of 200 to $400 \mathrm{~m}$ in the Indian and Pacific oceans (Inoue \& Okutani 1987). Specimens of its synonymous species, Gigantonotum album Lin \& Tchang and Pleurobranchoides gilchristi O'Donghue, have been reported from 200 to $400 \mathrm{~m}$ depths off South Africa and Mozambique as well as in Aden Bay, Somalia, and the Philippine, South China and Tasman seas (Lin \& Tchang 1965, Marcus \& Gosliner 1984, Inoue \& Okutani 1987). Thus, the collection of the strictly benthic (non-swimming) predator, P. nicobarica, from $612 \mathrm{~m}$ depth is regarded as the greatest depth recorded for this species.

From 2002 onwards, the benthopelagic holothurian Enypniastes eximia (ID 29) was collected, with a maximum catch of 12 individuals per day (1 January 2005) and a total catch of 106 individuals over the study period. E. eximia is distributed widely, e.g. in the Bahamas and New Zealand waters (Pawson 1982), as well as Japanese coastal waters at 300 to $3100 \mathrm{~m}$ depth (Mitsukuri 1912, Ohta 1985). This species is 
morphologically distinguished from another swimming but more spherical holothurian, Enypniastes globsa, found from 3400 to $3800 \mathrm{~m}$ in the South China Sea (Hansen \& Madsen 1956). One specimen of $E$. eximia (of 7) had 15 eggs in the ovary. The egg diameters were 2.1 to $3.1 \mathrm{~mm}$ with an average of $2.5 \mathrm{~mm}$ (Kuramochi et al. 2003), which is smaller than 3.0 to $3.5 \mathrm{~mm}$ reported for deep-dwelling holothurians (Billett 1991). It is unclear whether the size difference is ascribed to stages of maturity, habitats or intraspecific variations. No pelagic prey organisms were observed in the gut contents of the collected E. eximia, which indicates that this holothurian does not feed during swimming, but scavenges seafloor sediment (Kuramochi et al. 2003).

The apparent faunal change, i.e. decrease in the proportion of Pleurobranchella nicobarica and increase in Enypniastes eximia, is probably a result of the difference in their feeding habits. The feeding habits may be affected in turn by local deep-water production and regional fisheries. Influence of global warming should be tested by more detailed and longer observations. Seasonality was rarely clear during the studied period; however, slight seasonality was observed for the occurrence of Heterocarpus spp. Five species of the decapod crustacean, Heterocarpus, have been reported from Japanese waters (Baba et al. 1986), and 3 of them, $H$. laevigatus (ID 14), $H$. hayashii (ID 15) and $H$. sibogae (ID 16), were collected during this study. Specimens of $H$. laevigatus showed a tendency to appear in winter, while specimens of $H$. hayashii and $H$. sibogae were collected mostly from spring to summer. Egg-bearing individuals of $H$. hayashii were collected in March 2001, May 2001 and August 2000, although egg-bearing $H$. hayashii were previously reported in October in different Japanese waters. Seasonality in deep-sea organisms should be further examined by longer term observations.

The bottom-dwelling crustaceans, Thaumastocheles japonica (ID 19), Polycheles enthrix (ID 20), Munida pilosimanus (ID 21), Catapagurus doederleini (ID 25) and Platymaia fimbriata (ID 27), were also collected. The shrimp family of Polychelidae has been re-classified into 5 genera of Cardus, Homeryon, Pentacheles, Polycheles and Willemoesia (Galil 2000). Eight species of the genus Polycheles have been reported from Japanese waters (Galil 2000), and the species collected in this study, $P$. enthrix, is morphologically distinguishable from other species of this genus. Some specimens of $P$. enthrix were collected alive and showed sand-burrowing behavior with occasional swimming (Kuramochi et al. 2004a). However, burrow holes were hardly found in situ around the suction inlet when photographed. It is also unclear whether $T$. japonica and other in situ shrimps are sand-burrowers like Acanthacaris caeca (Holthuis 1974) or bottom-crawlers like Nephropsis stewarti (Iwata et al. 1992). In any case, it should be assumed that the bottom-dwelling crustaceans do exhibit swimming behavior and are accidentally entrained into the forced suction current near the water inlet $1.5 \mathrm{~m}$ above the seafloor. This may also be the case for the demersal fish, Solocisquama stellulatus (ID 57), which has been reported from 326 to $369 \mathrm{~m}$ depth off Hawaii, $476 \mathrm{~m}$ depth off South Africa, and $550 \mathrm{~m}$ depth in the Philippine Sea (Mochizuki 1982, Bradbury 1999), but reported for the first time from the Okinawa water in this study.

Shinohara et al. (2005) reported the occurrence of 643 fish species in the Okinawa area, including most of the species suctioned offshore from Kume Island; however, 3 fish species, namely Ateleopus spp. (ID 46 and 47), Halicmetus sp. (ID 56) and Cyrptopseras couesii (ID 58), were newly found in the Okinawa area in this study. In particular, the triple-wart sea-devil C. couesii has been reported widely from 75 to $4000 \mathrm{~m}$ depth in waters from $63^{\circ} \mathrm{N}$ to $43^{\circ} \mathrm{S}$ (Tanaka 1908, Imai 1941, Pietsch 1986), as well as in the Okinawa area in this study, and contributes to transport of material from shallow to deep waters (Marshall 1979). Another interesting finding was the species of home shells of the hermit crab Catapagurus doederleini (ID 25). The hermit crab used shells of the snail Pisanianura breviaxe (dwelling at $100 \mathrm{~m}$ depth), the underwater cavedwelling snail Neritopsis radula and even the terrestrial snail Achatina fulica. This finding indicates that material of shallow water and terrestrial origin can migrate into deep water and influence life histories of the fauna in that habitat.

Although not targeted in this study, adults of 2 cirriped species, Heteralepas japonica and Poecilasma kaempferi, were found attached to the wall of the onland pit for pumped deep water (Kuramochi et al. 2004b). These species are known to exist at depths from 18 to $2000 \mathrm{~m}$ in major oceans (Foster \& Buckeridge 1994, 1995, Ikeda et al. 2000). As the adults are strictly sessile, the occurrence inside the deepwater pit suggests that drifting eggs and/or larvae were suctioned and remained to settle in the pit. These drifter-derived specimens do not necessarily reflect the in situ benthic fauna. This study may have missed organisms lost through the $10 \mathrm{~mm}$ mesh screen, including epibenthic copepods and other amphipods. Soft-bodied gelatinous organisms may have also been missed. These organisms may make important contributions to material transport and cycling at the sediment-water interface, and long-term collection of these organisms may yield significant findings as well. 


\section{CONCLUSIONS}

Long-term observation at a deepwater facility yielded new knowledge of the occurrences and possibly behaviors of deepwater dwellers, and also showed temporal variability in their abundances. The latter may reflect inter-annual trends, not seasonal variations. This variability should be seriously considered and assessed to understand natural background trends before such communities are exposed to human exploitation and intervention.

Acknowledgements. We thank M. Ogawa for discussions of the results. We acknowledge a grant to T.N. from the Kanmonkai Corporation.

\section{LITERATURE CITED}

Baba K, Hayashi K, Toriyama M (eds) (1986) Decapod crustaceans from continental shelf and slope around Japan. Japan Fisheries Resource Conservation Association, Tokyo

Billett DSM (1991) Deep-sea holothurians. Oceanogr Mar Biol Ann Rev 29:259-317

Bradbury MG (1999) A review of the fish genus Dibranchus with descriptions of new species and a new genus Solocisquama (Lophiiformes, Ogcocephalidae). Proc Calif Acad Sci 51:259-310

Foster BA, Buckeridge JS (1994) Barnacles (Cirripedia, Thoracia) of seas off Reunion Islands and the East Indies. Bull Mus Hist Nat Paris A Zool 16:345-382

Foster BA, Buckeridge JS (1995) Barnacles (Cirripedia, Thoracia) of seas off the Straits of Gibraltar. Bull Mus Hist Nat Paris A Zool 17:163-192

Galil BS (2000) Crustacea Decapoda: review of the genera and species of the family Polychelidae Wood-Mason, 1874. MUSORSTOM, Vol 21. Mem Mus Natl Hist Nat 184: 285-387

Hansen B, Madsen FJ (1956) On two bathypelagic holothurians from the South China Sea. Galathea Rep 2:55-59

Holthuis LB (1974) The lobsters of the superfamily Nephropidea of the Atlantic Ocean (Crustacea: Decapoda). Bull Mar Sci 24:723-884

Ikeda H, Kuramochi T, Watanabe M (2000) Lepadomorpha (Crustacea: Cirripedia) collected from Sagami Bay, coast of Miura Peninsula, central Japan. Nat Hist Rep Kanagawa 21:41-44

Imai S (1941) Seven new deep-sea fishes obtained in Sagami Sea and Suruga Bay. Jpn J Zool 9:233-250

Editorial responsibility: Otto Kinne,

Oldendorf/Luhe, Germany
Inoue R, Okutani $\mathrm{T}$ (1987) Pleurobranchella nicobarica Thiele, 1925, new to the Japanese Notaspidae fauna. Venus 46:219-225

Iwata Y, Sugita H, Deguchi Y, Kanemoto FI (1992) Behavior of Nephropsis stewarti Wood-Mason (Decapod, Nephropidae) in an aquarium. Crustac Res 21:59-63

Kuramochi T, Sudo Y, Ogawa M, Tamaki E, Naganuma T (2003) Record of Cryptosara couesii Gill (Lophiiformes: Ceratiidae) from off-Kume Island, Ryukyu Islands, western Japan, J Grad Sch Biosp Sci 42:11-14 (in Japanese with English abstract)

Kuramochi T, Sudo Y, Ogawa M, Tamaki E, Naganuma T (2004a) Record of Polycheles enthrix (Decapoda: Polycheliidae) from off-Kume Island, Ryukyu Islands, southwestern Japan. J Grad Sch Biosp Sci 43:1-6 (in Japanese with English abstract)

Kuramochi T, Sudo Y, Ogawa M, Tamaki E, Naganuma T (2004b) Note on Lepadomorpha (Cirripedia, Pedunculata) collected from off Kume Island, Ryukyu Islands, western Japan. Nankiseibutsu (The Nanki Biological Society) 46:161-162 (in Japanese with English captions)

Lin GY, Tchang S (1965) Opisthobranch mollusks from the southern tropical Pacific. Pac Sci 24:155-179

Marcus E, Gosliner TM (1984) Review of the family Pleurobranchaeidae (Mollusca, Opisthobranchia). Ann S Afr Mus 93:1-53

Marshall NB (1979) Developments in deep-sea biology. Blanford Press, Poole

Mitsukuri K (1912) Studies on Actinopodus Holothurioidea. J Coll Sci Imp Univ Tokyo 19:1-284

Mochizuki K (1982) Priacanthidae, Apogonidaw, Scombropidae. In: Okamura O, Amaoka K, Mitani F (eds) Fishes of the Kyushu-Palau Ridge and Tosa Bay, and slope around Japan. Japan Fisheries Resource Conservation Association, Tokyo, p 224-229

Ohta S (1985) Photographic observation of the swimming behavior of the deep-sea pelagothuriid holothurian Enypniastes (Elasipoda, Holothurioidea). J Oceanogr Soc Japan 41:121-133

Pawson DL (1982) Deep-sea echinoderms in the Tongue of the Ocean, Bahama Islands: a survey, using the research submersible Alvin. Aust Mus Mem 16:129-145

Pietsch TW (1986) Systematics and distribution of bathypelagic anglerfishes of the Family Ceratioidae (Order: Lophiiformes). Copeia 1986:479-495

Shinohara G, Sato T, Aonuma Y, Horikawa H, Matsuura K, Nakabo T, Sato K (2005) Annotated checklist of deep-sea fishes from the waters around the Ryukyu Islands, Japan. Deep-Sea fauna and pollutants in the Nansei Islands. Natl Sci Mus Monogr 29:385-452

Tanaka S (1908) Notes on some rare fishes of Japan, with description of two new genera and six new species. J Coll Sci Imp Univ Tokyo 23:18-24

Submitted: June 14, 2007; Accepted: November 8, 2007

Proofs received from author(s): March 20, 2008 